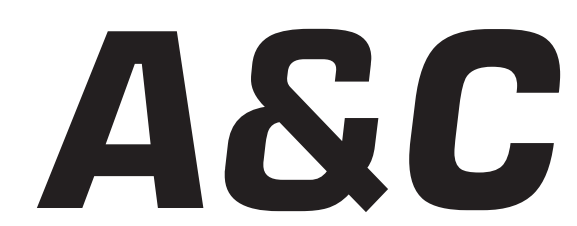

Revista de Direito Administrativo \& Constitucional



ISSN 1516-3210 


\section{A\&C REVISTA DE DIREITO ADMINISTRATIVO E CONSTITUCIONAL}

IPDA

Instituto Paranaense

de Direito Administrativo

Direção Geral

Romeu Felipe Bacellar Filho

Direção Editorial

Paulo Roberto Ferreira Motta

Direção Executiva

Emerson Gabardo

Conselho de Redação

Edgar Chiuratto Guimarães

Adriana da Costa Ricardo Schier

Célio Heitor Guimarães

\section{Conselho Editorial}

Adilson Abreu Dallari

Alice Gonzáles Borges

Carlos Ari Sundfeld

Carlos Ayres Britto

Carlos Delpiazzo

Cármen Lúcia Antunes Rocha

Celso Antônio Bandeira de Mello

Clèmerson Merlin Clève

Clóvis Beznos

Enrique Silva Cimma

Eros Roberto Grau

Fabrício Motta

Guilhermo Andrés Muñoz (in memoriam)

Jaime Rodríguez-Arana Muñoz

Jorge Luís Salomoni

José Carlos Abraão
José Eduardo Martins Cardoso
José Luís Said
José Mario Serrate Paz
Juan Pablo Cajarville Peruffo
Juarez Freitas
Julio Rodolfo Comadira
Luís Enrique Chase Plate
Lúcia Valle Figueiredo
Manoel de Oliveira Franco Sobrinho
(in memoriam)
Marçal Justen Filho
Marcelo Figueiredo
Márcio Cammarosano
Maria Cristina Cesar de Oliveira

Nelson Figueiredo

Odilon Borges Junior

Pascual Caiella

Paulo Eduardo Garrido Modesto

Paulo Henrique Blasi

Paulo Neves de Carvalho (in memoriam)

Paulo Ricardo Schier

Pedro Paulo de Almeida Dutra

Regina Maria Macedo Nery Ferrari

Rogério Gesta Leal

Rolando Pantoja Bauzá

Sérgio Ferraz

Valmir Pontes Filho

Yara Stropa

Weida Zancaner

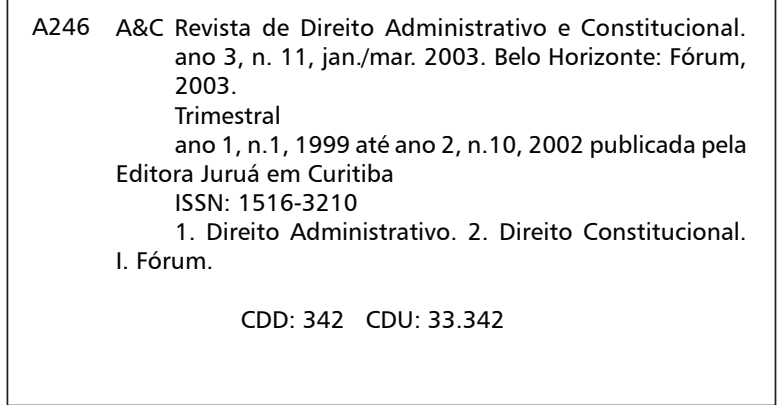

(C) Editora Fórum Ltda. 2007

Todos os direitos reservados. É proibida a reprodução total ou parcial, de qualquer forma ou por qualquer meio eletrônico ou mecânico, inclusive através de processos xerográficos, de fotocópias ou de gravação, sem permissão por escrito do possuidor dos direitos de cópias (Lei nº 9.610, de 19.02.1998).

Editora Fórum Ltda

Av. Afonso Pena, 2770 - 15\%16ª andar - Funcionários

CEP 30130-007 - Belo Horizonte/MG - Brasil

Tel.: 08007043737

Internet: www.editoraforum.com.br

e-mail: editoraforum@editoraforum.com.br
Editor responsável: Luís Cláudio Rodrigues Ferreira Projeto gráfico e diagramação: Luis Alberto Pimenta Revisora: Olga M. A. Sousa

Pesquisa jurídica: Fátima Ribeiro - OAB/MG 74868

Bibliotecária: Alessandra Rodrigues da Silva CRB 2778/MG 6 ${ }^{\text {a Região }}$

Os conceitos e opiniões expressas nos trabalhos assinados são de responsabilidade exclusiva de seus autores.

Impressa no Brasil / Printed in Brazil

Distribuída em todo Território Nacional 


\title{
Afastamento da função jurisdicional de magistrado, em virtude de processo administrativo disciplinar, não poderá exceder 120 dias - Inteligência do art. 147 , da Lei $\mathrm{n}^{\circ} 8.112 / 90$
}

\begin{abstract}
Mauro Roberto Gomes de Mattos
Advogado no Rio de Janeiro-RJ. Autor de inúmeras obras jurídicas. Vice-Presidente do Instituto Ibero-Americano de Direito Público (Capítulo Brasileiro) (IADP). Membro da Sociedade Latino-Americana de Direito do Trabalho e Seguridade Social. Membro do IFA (International Fiscal Association). Conselheiro efetivo da Sociedade Latino-Americana de Direito do Trabalho e Seguridade Social. Co-Coordenador da Revista Ibero-Americana de Direito Público (RIADP) (Órgão de Divulgação Oficial do IADP).
\end{abstract}

Palavras-chave: Direito processual disciplinar. Processo administrativo disciplinar. Poder Judiciário. Magistrado.

Sumário: 1 Considerações iniciais - 2 Noção de prazos no Direito Processual Disciplinar - 3 Duração razoável do processo administrativo disciplinar 4 Afastamento das funções judicantes do magistrado em razão de processo disciplinar não pode exceder 120 dias - 5 Conclusão

\section{Considerações iniciais}

A Emenda Constitucional $\mathrm{n}^{\mathrm{o}} 45$, de 31.12.2004, acrescentou o inciso LXXVIII, ao artigo $5^{\circ}$, da CF, com a seguinte redação: “— a todos, no âmbito judicial e administrativo, são assegurados a razoável duração do processo e os meios que garantam a celeridade de sua tramitação".

Este direito/garantia fundamental constitucional, extensivo ao processo administrativo disciplinar, é de grande relevância para todos os servidores públicos da União visto que, nas apurações dos processos anteriormente mencionados, a tramitação dos mesmos se arrastam por longos anos, com prejuízo ao erário público pelo pagamento de infindáveis e rendosas diárias aos componentes de Comissão Disciplinar, bem como ao mesmo tempo acarretando injustiça e o constrangimento para o servidor público por ser objeto de investigação durante vários lustros, com transtornos de toda ordem e com isso havendo inclusive o ferimento de sua honra objetiva e subjetiva.

O lapso de tempo para a prática dos atos processuais e a conclusão do processo administrativo disciplinar vem estipulado na Lei, para não 
permitir excessos de prazos por parte de quem apura a existência ou não de uma infração disciplinar praticada, em tese, por um servidor público.

A indeterminação do lapso temporal da investigação traz, além de descréditos, a possibilidade da ocorrência da prescrição intercorrente, visto que o $\mathrm{STF}^{1}$ pacificou o entendimento que a instauração de sindicância ou a tramitação do processo administrativo disciplinar só interrompem o prazo prescricional por 140 (cento e quarenta) dias, voltando a fluir após este período.

Isto porque os 140 dias são alusivos à conclusão do processo administrativo disciplinar e a imposição de pena (arts. 152 e 167, da Lei $\left.\mathrm{n}^{\mathrm{o}} 8.112 / 90\right)$ para as situações jurídicas dos servidores públicos federais. Tal princípio (prescrição intercorrente) é aplicável também aos processos que envolvam servidores públicos estaduais e municipais, que possuem de igual forma em seus Estatutos a fixação de prazos previamente estabelecidos para a tramitação e o julgamento dos processos disciplinares. Portanto, o único diferencial poderá ser quanto ao prazo máximo previsto em cada Estatuto jurídico, pois o princípio da prescrição intercorrente é o mesmo para todos os servidores públicos, visto que a prescritibilidade dos atos públicos é a norma fundamental para todo o ordenamento jurídico (CF, art. 37, $\left.\S 5^{\circ}\right)$.

Em assim sendo, a presente inserção constitucional estabelecida pela Emenda Constitucional $\mathrm{n}^{\mathrm{o}} 45 / 2004$, (art. 5 ${ }^{\circ}$, LXXVIII, da CF), traz a obrigação legal do processo administrativo, incluído nesse rol o disciplinar, tramitar em tempo razoável qual seja, o previsto na legislação infraconstitucional.

Para não ser tida como inócua e inoperante dentro dos direitos e das garantias fundamentais constitucionais do servidor público, cabe ao operador do direito aplicar eficazmente esta nova disposição constitucional como um real e verdadeiro mandamento, um dever e obrigação, para que ela não deixe de ser observada e pelo seu sucessivo descumprimento e inobservância, caia em desuso.

Tal orientação deve ser um poder-dever para as Administrações Públicas, pois, do contrário, continuará a eternização dos feitos disciplinares, com grave prejuízo para todos. Não é mais concebível que o Poder Público

\footnotetext{
BRASIL. Supremo Tribunal Federal. RMs no 23.436/DF. Órgão julgador: 2a Turma. Relator: Min. Marco Aurélio. DJ, p. 28, 15 out. 1999 e RMS n 21.562/DF. Órgão julgador: $1^{a}$ Turma. Relator: Min. IImar Galvão. p. 16.637.
}

A \& C R. de Dir. Administrativo e Constitucional, Belo Horizonte, ano 7, n. 28, p. 129-149, abr./jun. 2007 
gaste milhões de reais com o pagamento de diárias e despesas desnecessárias, criadas pela própria lentidão das Comissões Disciplinares, que auferem vantagens indevidamente, interligadas à sua própria morosidade. É um verdadeiro "achado" para o trio processante disciplinar o recebimento de diárias ad eternum, enquanto o investigado sofre adversidades de toda ordem pelo transcurso do tempo sem uma decisão final.

Para combater e extirpar esta imoralidade, o inciso LXXVIII, do art. $5^{\circ}$, da CF foi concebido pelo Legislador Constitucional.

Contudo, para o presente dispositivo constitucional ser cumprido exemplarmente, o Poder Judiciário deverá punir a Administração Pública pela perda do direito de apurar e de punir o servidor público disciplinarmente se excedido o "prazo razoável" a que alude a norma prevista na Lei fundamental ora em comento.

Do contrário, a norma constitucional fundamental sub oculis cairá em desuso, pois é cediço que, se não houver uma sanção, o ente de direito público não cumprirá o que vem estatuído na citada norma.

O Direito Constitucional é tido como um sistema de garantias para todo o ordenamento jurídico.

Assim sendo, cabe ao Estado tornar eficaz os princípios e as normas constitucionais, como condição sine qua non de manutenção da própria democracia e, via de conseqüência, deverá "estar atento aos valores fundamentais do homem", ${ }^{2}$ pois do contrário haverá a violação do próprio sistema de normas jurídicas.

Preocupa-nos a falta de seriedade e responsabilidade das Comissões Disciplinares em geral, respaldadas pelas Autoridades que as nomeiam, fazendo do processo administrativo disciplinar uma ineficiente eternização no tempo, em detrimento da dignidade, inclusive moral, do servidor investigado.

Este novel inciso LXXVIII, do art. $5^{\circ}$, da CF, possui o objetivo de colocar de vez por todas um fim à morosidade dos processos administrativos disciplinares, visto que não se admite mais a sua tramitação desordenada e desatrelada de uma duração razoável, prevista em Lei infraconstitucional.

Sendo certo que as regras do processo administrativo disciplinar

\footnotetext{
2 SOARES, Rogério Ehrhardt. Direito constitucional: introdução, o ser e a ordenação jurídica do Estado. In: CUNHA, Paulo Ferreira da (Org.). Enciclopédia jurídica. Instituições de direito. Coimbra: Almedina, 2000. v. 2, p. 511.
} 
do funcionário público federal, a que alude a Lei $n^{\circ} 8.112 / 90$, são aplicadas aos Magistrados, pois a LOMAN não estabelece ritos processuais administrativos. Desta forma, visando dinamizar o processo disciplinar dos Juízes, o artigo 83 do Regimento Interno do Eg. Conselho Nacional de Justiça (CNJ) estabeleceu, no que não for incompatível, a aplicação da Lei $n^{\circ} 8.112 / 90$ e da Lei ${ }^{\circ}$ 9.784/99.

Não resta dúvida que o $\mathrm{CNJ}$ deu um grande avanço na moralização da apuração dos processos disciplinares dos Juízes, visto que eles se afastavam durante infindáveis anos, excedendo a razoabilidade do tempo, porquanto não possuíam prazos de afastamento do Magistrado e de encerramento do respectivo procedimento.

Em boa hora, o CNJ não permite o afastamento do Magistrado, em virtude de apuração disciplinar, por mais de 120 dias, pois aplica-se o que vem estatuído no artigo 147 , da Lei ${ }^{\circ} 8.112 / 90$.

\section{Noção de prazos no Direito Processual Disciplinar}

José Frederico Marques ${ }^{3}$ estabelece que "prazo é o espaço de tempo para o ato processual ser praticado."

Este limite temporal, estabelecido na figura jurídica do prazo, é uma das conseqüências do princípio da celeridade processual, visto que a jurisdição tem que ser plena e em tempo útil, sem dilações indevidas.

Nesse sentido, Cândido Rangel Dinamarco estabelece no prazo "a distância temporal entre dois fatos ou atos"4 previamente estipulados em lei, que obrigam as partes a se manifestarem tempestivamente, sob pena da perda de determinada faculdade.

Não resta dúvida que o prazo é destinado à prática de atos processuais das partes, que excedidos ou inobservados, produzem conseqüências e efeitos de caráter processual.

Mesmo no processo administrativo disciplinar que não possui o rigorismo do processo civil ou penal, também existem prazos preclusivos, tais como a perda da produção de determinada prova ou de razões finais. Neste procedimento não é admissível a revelia, sendo dever do poder público constituir defensor dativo caso o servidor acusado não possua recursos para ser representado por procurador privado, ou se negue a se defender no feito.

3 MARQUES, José Frederico. Manual de direito processual civil. Campinas: Bookseller, 1997. v. 1, p. 468.

4 DINAMARCO, Cândido Rangel. Instituições de direito processual civil. 5. ed. São Paulo: Malheiros, 2005. t. 2, p. 550 .

A \& C R. de Dir. Administrativo e Constitucional, Belo Horizonte, ano 7, n. 28, p. 129-149, abr./jun. 2007 
Sucede que o legislador infraconstitucional estabeleceu prazo para a instrução, apuração e julgamento do processo administrativo disciplinar que quase sempre é desrespeitado pelas Autoridades competentes responsáveis em face ao descumprimento dos mesmos, transformando as apurações internas em uma lenta e cansativa tramitação, de forma ilegal, visto que compete ao próprio poder público apurar e julgar, nomeando servidores públicos para tal fim. Do ponto de vista jurídico, não existe justificativa legal para tamanho descaso, negligência e incúria com os prazos previamente estipulados pela Lei para a investigação e para a aplicação da pena, ao servidor público investigado.

Como o Poder Judiciário inúmeras vezes identificou a falta de prejuízo para as partes, quando excedido o prazo legal da conclusão do processo administrativo disciplinar, possibilitou a criação de verdadeira praxe, caracterizada pelo respectivo descaso das normas infraconstitucionais que impõem a conclusão dos processos administrativos disciplinares em tempo pré-fixado, com a aplicação de penalidades ao servidor público infrator de um dever funcional.

Sucede que, com a obrigação constitucional da "duração razoável" do processo administrativo e do judicial erigida como uma garantia fundamental da parte, houve uma vertiginosa alteração da situação legal anterior, visto que o encerramento dos feitos não poderá ser mais no dia e na hora (discricionariamente) que a autoridade administrativa entende como correta, pois a razoabilidade dos prazos consiste naqueles já definidos anteriormente pela lei.

O tempo de realização dos atos processuais administrativos, agora, deve ser cumprido tempestivamente, pois do contrário será violado um direito fundamental do acusado, que deverá ser julgado em até 140 (cento e quarenta) dias da instauração do processo administrativo disciplinar e não poderá mais ser afastado de suas funções em prazo que exceda 120 dias. Foi necessária uma Emenda à Constituição para estabelecer a obrigatoriedade do processo administrativo disciplinar ser concluído no prazo já estabelecido anteriormente (“duração razoável”), visto que esta já deveria ser uma condição normal e habitual na conduta das Autoridades que presidem os processos.

Esta desconsideração temporal, ou seja, este desrespeito absoluto para com os prazos estabelecidos na legislação infraconstitucional por parte do poder público, além de violar o princípio da oficialidade, que advém do princípio da eficiência (CF, art. 37), gera um grande descrédito para 
com os atos emanados da Administração Pública.

Os prazos processuais são absolutos ou relativos, segundo lição de Carnelutti, ${ }^{5}$ que define a primeira situação jurídica como: "La circunscripción temporal es absoluta cuando el acto debe cumplirse en un período determinado del tiempo."

A perda de um prazo simples ou absoluto acarreta a preclusão, com a perda de determinado direito para a parte que foi negligente e não observou o prazo legal.

A sujeição da atividade administrativa a prazos é uma condição da processualidade, visto que o princípio da oficialidade estabelece o dever do impulso da Administração Pública, que deverá concluir o processo administrativo disciplinar em tempo útil, sem delongas desarrazoadas, ${ }^{6}$ sob pena de responsabilidade dos responsáveis pelo bom e célere andamento do mesmo. ${ }^{7}$

O descrédito da Administração Pública com os prazos de apuração, conclusão e de julgamento no processo administrativo disciplinar se deve ao fato da lei não estabelecer expressamente a perda de sua faculdade de punir, com a responsabilização das Autoridades competentes pela sua inércia.

A Lei no 8.112/90 — Regime Jurídico Único dos Servidores Públicos da União - , fixou o prazo de 140 (cento e quarenta) dias como o prevalente para a conclusão do processo administrativo disciplinar e a conseqüente imposição de pena (arts. 152 e 167) para o servidor público que viole um dever funcional. Este é o prazo razoável estabelecido pela lei, visto que compete à própria Administração Pública apurar e punir o servidor público que tenha infringido um dever legal.

Por esta razão, o legislador previu 140 (cento e quarenta) dias como sendo o prazo legal para a duração da investigação e conclusão, inclusive com aplicação de pena ou não no âmbito do processo administrativo disciplinar federal.

\footnotetext{
5 CARNELUTTI, Francesco. Instituciones del processo civil. Tradução de: Santiago Sentís Melendo. Buenos Aires: Livr. del Foro, 1997. v. 1, p. 521.

6 "O princípio da oficialidade, também denominado de impulso oficial ou impulsão de ofício, significa que cabe à Administração tomar todas as providências necessárias ao trâmite contínuo para se chegar, sem delongas, à decisão final" (MEDAUAR, Odete. A processualidade no direito administrativo. São Paulo: R. dos Tribunais, 1993. p. 120).

7 "Se a Administração o retarda ou dele se desinteressa, infringe o princípio da oficialidade e seus agentes podem ser responsabilizados pela omissão" (MEIRELLES, Hely Lopes. Direito administrativo brasileiro. 15. ed. São Paulo: Malheiros, 1989. p. 580).
} 
Esta regra temporal é uma necessidade da processualidade no direito administrativo federal em geral, pois, do contrário, teríamos a tramitação de processos que nunca chegariam ao seu desfecho.

O dever de celeridade consta em quase todos os ordenamentos administrativos do direito comparado, como por exemplo, no Código do Procedimento Administrativo de Portugal, ${ }^{8}$ onde no seu art. 57, vem estabelecido: "Art. 57 - Os Órgãos administrativos devem providenciar pelo rápido e eficaz andamento do procedimento, quer recusando e evitando tudo que for impertinente ou dilatório, quer ordenando e promovendo tudo o que for necessário ao seguimento do procedimento e à justa e oportuna decisão.”

Estabeleceu o artigo 58 do referido Código de Procedimento Administrativo Português 90 (noventa) dias como o prazo alusivo à conclusão do processo administrativo (art. 58.1), podendo ser prorrogado por um ou mais períodos, até o limite de mais 90 (noventa) dias (art. 58.2), devendo a inobservância dos respectivos prazos ser justificada pelo órgão responsável, perante o imediato superior hierárquico ou perante o órgão colegial competente, dentro de 10 (dez) dias seguintes (art. 58.3).

Sucede que, para penalizar a inércia da Administração Pública, quando deixa de cumprir os prazos estabelecidos previamente, o artigo 108, do Decreto-Lei $n^{\circ} 442 / 91$, estabelece deferimento tácito da formulação do pedido de requerimento administrativo pelo administrado: "Art. 108.1 - Quando a prática de um acto administrativo ou exercício de um direito por um particular dependam de aprovação ou autorização de um órgão administrativo, consideram estas concedidas, salvo disposição em contrário, se a decisão não for proferida no prazo estabelecido por lei. 2 - Quando a lei não fixar prazo especial, o prazo de produção do deferimento tácito será de 90 (noventa) dias a contar da formulação do pedido ou da apresentação do processo para esse feito. 3 - Para os efeitos do disposto neste artigo, consideram-se dependentes de aprovação ou autorização de órgão administrativo, para além daqueles relativamente aos quais leis especiais prevejam o deferimento tácito, os casos de: a) Licenciamento de obras particulares; b) Alvarás de loteamento; c) Autorizações de trabalho concedido a estrangeiros; d) Autorizações de investimento estrangeiro; e) Autorização para laboração contínua;

8 Decreto-Lei n 442, de 15 de novembro de 1991, com as alterações introduzidas pelo Decreto-Lei $n^{\circ} 6$, de 31 de janeiro de 1996.

A \& C R. de Dir. Administrativo e Constitucional, Belo Horizonte, ano 7, n. 28, p. 129-149, abr./jun. 2007 
f) autorização de trabalho por turnos; g) Acumulação de funções públicas e privadas."

Nas situações jurídicas descritas no citado artigo, o "efeito é o deferimento da pretensão formulada ao órgão administrativo e decorre ex lege do silêncio da Administração."9

A Constituição da República Portuguesa estabelece em seus artigos 20.4 e 20.5, o acesso ao direito e à tutela jurisdicional efetiva, aí incluída a jurisdição administrativa, de modo a ser concedida em tempo útil. ${ }^{10}$

Tanto os números 4 e 5 do art. 20, da Constituição de Portugal foram inspirados pelo art. $6^{\circ}$, da Convenção Européia dos Direitos do Homem. ${ }^{11}$

Na Espanha, a Administração Pública está sujeita também aos prazos previstos como condição de validade para os seus próprios atos.

Neste sentido, o artigo 42 da Lei de Regime Jurídico das Administrações Públicas e Procedimento Comum — Lei no 30, de 26.11.92 — com a redação dada pela Lei n ${ }^{\circ}$ 4, de 13.1.99, estabelece: "42.1 - La Administração está obligada a dictar resolución expresa en todos los procedimientos y a notificarla cualquiera que sea su forma de inciciación (...) 42.2 - El plazo máximo en el que debe notificarse la resolución expressa será el fijado por la norma reguladora del correspondiente procedimiento. Este plazo no podrá exceder de seis meses salvo que una norma con rango de ley establezca uno mayor o así venga prevista en la normativa comunitaria europea. 42.3 - cuando las normas reguladoras de los procedimientos no fijen el plazo máximo, este será de tres meses. Este plazo y los previstos en el apartado anterior se contraían: A) En los procedimientos iniciados de oficio, desde la fecha del acuerdo de iniciación. B) En los iniciados a solicitud del interesado, desde la fecha en que la solicitud haya tenido entrada en el registro del órgano competente para su tramitación.”

Pela redação do artigo 42.2 é prevista a duração de todos os procedimentos administrativos, abrangidos os iniciados pela Administração Pública (disciplinares) como os que se originam de requerimento do interessado, e devem tramitar respeitando a seguinte regra jurídica: ${ }^{12}$

\footnotetext{
9 OLIVEIRA, Mário Esteves de; GONÇALVES, Pedro Costa; AMORIM, J. Pacheco. Código de procedimento administrativo comentado. 2. ed. Coimbra: Almedina, 1999. p. 477.

10 "Art. 20.4 - Todos têm direito a que uma causa em que intervenham seja objecto de decisão em prazo razoável e mediante processo eqüitativo".

"20.5 - Para defesa dos direitos, liberdades e garantias pessoais, a lei assegura aos cidadãos procedimentos judiciais caracterizados pela celeridade e prioridade, de modo a obter tutela efectiva e em tempo útil contra ameaças ou violações desses direitos."

${ }^{11}$ Cf. SOUSA, Marcelo Rebelo; ALEXANDRINO, José de Mello. Constituição da República Portuguesa comentada. Lisboa: Lex, 2000. p. 103.
} 
- prazo normal e geral: seis meses;

- prazo superior ao normal: são estabelecidos em lei e superam os seis meses do prazo normal, que segundo a Lei 9, de 27.12.2001, decorre de Medidas Fiscais, de gestão administrativa e financeira chega a estipular o prazo máximo de 2 anos e o seu mínimo de 9 meses;

- prazo inferior ao normal: três meses para as hipóteses que os procedimentos não estabelecem prazo máximo algum.

Por sua vez, o artigo 24.1, da Constituição da Espanha, estabelece que toda pessoa possui direito de obter uma tutela efetiva dos juízes e tribunais, sem dilações indevidas (art. 24.2, CE). O Tribunal Constitucional da Espanha tem reiterado que constitui um direito fundamental à tutela judicial efetiva, configurando as dilações sem justificativas uma afronta a tal direito, visto que o processo deve desenvolver-se dentro de prazos temporais razoáveis (STC 75/1999).

Todavia, a mesma Corte Constitucional reconhece que a expressão "dilaciones indebidas" do art. 24.2, da CE é qualificada tecnicamente como um conceito jurídico indeterminado. ${ }^{13}$

Assim, para atingir o objetivo da tutela efetiva, sem dilações indevidas ou injustificadas, o Tribunal Constitucional da Espanha tem direcionado os seus julgamentos influenciado pelo Tribunal de Estrasburg, onde está localizado o Tribunal Europeu de Direitos Humanos, que estabeleceu o conceito de "prazo razoável" observando os seguintes fatores: complexidade do assunto; comportamento dos litigantes e de seus procuradores; e da atuação do órgão jurisdicional.

Já na Argentina, o Decreto-Lei $n^{\circ}$ 19.549/72 que estabelece as normas de Procedimentos Administrativos da cidade autônoma de Buenos Aires, logo em seu artigo inaugural estabelece (art. 1.b) a "celeridad, economia, sencillez y eficácia en los trámites. Celeridad, economia, sencillez y eficacia en los trámites quedando facultado el Poder Ejecutivo para regu lamentar el regime disciplinario que assegure el decoro y el orden procesal.”

Rafael Bielsa, ${ }^{14}$ em seu clássico Contencioso administrativo (1964), já preconizava a necessidade de se estabelecer a busca da verdade e a legali-

\footnotetext{
${ }^{12}$ Cf. PÉRES, Jesús Gonzáles; NAVARRO, Francisco Gonzáles. Comentarios a La Ley de Regimen Jurídico de Las Administraciones Publicas y Procedimiento Administrativo Comum (Ley 30/1992, de 26 de noviembre).

3. ed. Madrid: Thomson e Civitas, 2003. t. 1, p. 1.169.

${ }^{13}$ STC 36/84, 43/85, 113/88, 223/88, 28/89 e 81/89, dentre outras decisões.
}

A \& C R. de Dir. Administrativo e Constitucional, Belo Horizonte, ano 7, n. 28, p. 129-149, abr./jun. 2007 
dade da ação administrativa, através de meios probatórios idôneos e em prazos breves.

No âmbito da cidade de Buenos Aires, a Sala II, da Câmara de Apelações no Contencioso Administrativo e Tributário ${ }^{15}$ sobre o tema decidiu: "la eficacia de la actividad administrativa en gran medida de la celeridad com que se ejerza. La celeridad, economia, vencillez y eficacia de los trámites son principios fundamentales en el procedimiento administrativo moderno y así lo ha entendido expresamente el legislador consagrándolos en el articulo 22, inciso $b$, de la ley de procedimientos administrativos de la CABA."

O Regulamento de Investigações Administrativas, aprovado pelo Decreto $n^{\circ}$ 467/99 estabelece o dever de celeridade: "Art. 26 - A fin de que las investigaciones se efectúen com la mayor celeridad posible, se considerá trámite de urgencia todo lo referente a la sustanciación de los mismas, salvo codificación expressa de 'muy urgente' impuesta por el instructor."

Estes exemplos extraídos do direito comparado fortalecem a tese da necessidade da célere tramitação do processo administrativo disciplinar, visto que ele não pode se eternizar no tempo.

Em prol da segurança jurídica, o ordenamento jurídico cria prazos e garante o due process of law, com o amplo direito de defesa, exatamente para as partes cientificarem-se de seus direitos e de seus deveres, que se forem exercidos de forma serôdia e intempestiva serão afetados, pois não se concebe a eternização dos mesmos, com grande prejuízo ao servidor público investigado, que se perder um prazo é penalizado com a preclusão, ao passo que o Poder Público fica imune à mesma preclusão se descumprir os prazos aos quais está vinculado.

Pensar de modo diverso é desprezar o tempo que "é uma dimensão inseparável do processo", ${ }^{16}$ além de defender a ausência de isonomia processual. ${ }^{17}$

\section{Duração razoável do processo administrativo disciplinar}

\footnotetext{
${ }^{14}$ BIELSA, Rafael. Sobre lo contencioso administrativo. 3. ed. Buenos Aires: Librería y Ed. Costellví S. A., 1964. p. 151

15 "Contencioso Administrativo e Tributário, Sala II, LUNA, Carlos Ernesto, v. GCBA s/amparo", sentença de
}

A \& C R. de Dir. Administrativo e Constitucional, Belo Horizonte, ano 7, n. 28, p. 129-149, abr./jun. 2007 
Vigora na instância disciplinar o dever do poder público de apurar irregularidades praticadas por seus servidores públicos.

Sucede que o direito de investigação não é eternizado, visto que o princípio da prescritibilidade do ato administrativo é o prevalente.

Quando se trata de investigar infração disciplinar também vigora o princípio da prescrição, inclusive a intercorrente, como amplamente defendido pela doutrina e pelo Poder Judiciário.

Sucede que a expressão "razoável duração" do processo é indeterminada, visto que não fornece ao operador do direito critérios objetivos para a sua fiel aplicação.

Portanto, faz-se necessário analisar a expressão "duração razoável" utilizada para o processo administrativo disciplinar.

A Corte Européia dos Direitos do Homem, como já dito anteriormente, estabeleceu três critérios para avaliar a razoável duração do processo, levando em conta os seguintes fatores: complexidade do assunto; comportamento dos litigantes e de seus procuradores e da atuação do órgão jurisdicional.

Sobre a complexidade do assunto, ela não desperta grande polêmica no âmbito disciplinar, visto que as infrações são previstas no próprio Estatuto dos Servidores Públicos e as provas são, em sua grande maioria, oral e documental. Em algumas situações, que são raras, pode o caso investigado demandar a produção de prova pericial, que será produzida por um técnico ou especialista indicado pela Comissão Disciplinar. Mesmo nessa última situação, ficará esta incumbida da realização da perícia, na hipótese legal que comportar tal dilação probatória, realizando-se em um curto espaço de tempo, visto que compete ao próprio Poder Público e não à parte investigada, imprimir o devido ritmo legal aos andamentos dos trabalhos.

Assim sendo, os prazos estabelecidos na Lei no 8.112/90 (140 dias) para a conclusão e a aplicação da penalidade não serão, em tese, prejudicados pela complexibilidade da apuração, visto que a matéria disciplinar é una e os fatos são apurados quase sempre na repartição pública em que o servidor acusado está lotado, não havendo inclusive dificuldade na produção de prova.

\footnotetext{
${ }^{16}$ FERRAZ, Sérgio; DALLARI, Adilson Abreu. Processo administrativo. São Paulo: Malheiros, 2003. p. 39.

17 "... quanto à paridade das partes no processo, deve-se buscá-la no seu sentido efetivo, de fato, escopo maior do direito processual civil, e não somente a igualdade jurídica formal" (NERY JÚNIOR, Nelson. Princípios do processo civil na Constituição Federal. 8. ed. São Paulo: R. dos Tribunais, 2004. p. 79).
} 
Sobre o comportamento das partes (poder disciplinar e servidor investigado), em consonância com a regra do respeito ao uso da lealdade e da boa-fé, reconhecidas para todos os tipos de Processos Administrativos Federais (arts. $2^{\circ}$, IV, e $4^{\circ}$, II, da Lei $n^{\circ} 9.784 / 99$ ), constitui-se dever das mesmas exercer seu mumus sem dilações indevidas. ${ }^{18}$ Devendo, via de conseqüência, ser preconizada uma atuação conforme a Lei e o Direito de forma eficiente, que apenas gerem o recebimento de diárias para os integrantes das Comissões Disciplinares, interligadas ao cumprimento do prazo estabelecido para a tramitação e para a conclusão do processo disciplinar (140 dias), pois do contrário este pagamento excedente ao prazo referido é considerado ato ilícito e incompatível com a moralidade pública.

Assim, não é concebível que na tramitação do processo administrativo disciplinar o comportamento das partes seja imbuído de má-fé e de descaso com a res publica, uma vez que a utilização da ampla defesa do servidor acusado é um dogma necessário à estabilização da própria situação jurídica investigada, visto que o processo justo exige a busca da verdade real.

Desta forma, a conjugação eficiente do tempo necessário para a apuração e a aplicação da pena, se a hipótese jurídica assim comportar, não poderá violar aos princípios do contraditório e da ampla defesa do acusado, com a utilização de todos os meios de provas admitidos em direito. Este transcurso normal do tempo impede que haja pagamento de diárias excedentes aos 140 dias para os componentes da Comissão Disciplinar.

O Poder Público responsável pela apuração e o servidor público investigado não devem causar dilações indevidas, mas sim agir de forma leal e honesta, direcionada para a busca da verdade real.

Por fim, a atuação das Autoridades (responsáveis pela apuração dos fatos e pelo respectivo julgamento) deve garantir a liberdade (ampla defesa), justiça (busca da verdade real) e segurança (utilização de todos os meios legais de prova) com uma rapidez que permita a duração normal do processo disciplinar, utilizando-se os necessários meios pessoais e materiais para o atingimento desta finalidade pública.

A garantia de um processo administrativo eqüitativo tornou-se um princípio fundamental da proeminência do Direito, direcionado tanto

\footnotetext{
18 "Art. $4^{\circ}$ - São deveres do administrado perante a Administração, sem prejuízo de ato normativo:

I - expor os fatos conforme a verdade; II - proceder com lealdade, urbanidade e boa-fé; III - não agir de modo temerário; IV - prestar as informações que Ihe forem solicitadas e colaborar para esclarecimento dos fatos."
}

A \& C R. de Dir. Administrativo e Constitucional, Belo Horizonte, ano 7, n. 28, p. 129-149, abr./jun. 2007 
para o servidor acusado como para o Poder Público.

Irineu Cabral Barreto ${ }^{19}$ entende como processo eqüitativo: "Um processo eqüitativo exige, como elemento co-natural, que cada uma das partes tenha possibilidades razoáveis de defender os seus interesses numa posição não inferior à parte contrária, ou, de outro modo, a parte deve deter a garantia de apresentar o seu caso perante o tribunal em condições que a não coloquem em substancial desvantagem face ao seu oponente.

Desta forma, a causa deve ser examinada num prazo razoável, "elemento essencial para uma boa administração da justiça." ${ }^{0}$

Com esta finalidade, ou seja, de exigir o respeito à utilização de um prazo razoável a Convenção Européia dos Direitos do Homem sublinha a importância que atribui à uma justiça administrada sem atrasos, que venha a corresponder a sua eficácia e credibilidade, ${ }^{21}$ conforme determinação expressa do seu art. 6.1: "Qualquer pessoa tem direito a que a causa seja examinada eqüitativamente e publicamente, num prazo razoável por um tribunal independente e imparcial, estabelecido pela lei...”

Entre nós, a garantia em questão está também expressamente consagrada no art. $8^{\circ}, \mathrm{n}^{\mathrm{o}} 1,{ }^{22}$ do Pacto de São José da Costa Rica, ratificado pelo Brasil através do Decreto $n^{\circ}$ 678, de 6 de novembro de 1992.

O disposto no art. $5^{\circ}$, LXXVIII, da CF, através da Emenda Constitucional $n^{\circ} 45 / 2007$, foi estabelecido para dar efetividade à duração de prazo razoável nas demandas judiciais e administrativas. É sabido que quanto às demandas judiciais, a expressão "duração razoável” do processo é algo inconclusivo, tendo em vista que a lide forense requer um lapso de tempo prolongado, não podendo ser resolvida em um instante único, em razão dos vários graus de jurisdição e da nem sempre rápida produção de provas e, por vezes, em razão da pluralidade das partes. Não sendo, portanto, possível delimitar de maneira precisa e fiel o alcance da norma jurídica sub oculis sem análise do caso concreto colocado sub judice.

\footnotetext{
19 BARRETO, Irineu Cabral. A Convenção Européia dos Direitos do Homem. Lisboa: Ed. Notícias Aequitas, 1995. p. 83.

${ }^{20}$ BARRETO, Irineu Cabral. A Convenção Européia dos Direitos do Homem. Lisboa: Ed. Notícias Aequitas, 1995. p. 100.

${ }^{21}$ Acórdãos do Tribunal Europeu dos Direitos do Homem: Guincho, A81, p. 16, §38; H/França, de 24 de outubro de 1989, A162, p. 22/23, §58 e Vernillo, de 20 de fevereiro de 1991, A198, p. 14, §38.

22 "Art. 8.1. - toda pessoa terá o direito de ser ouvida, com as devidas garantias dentro de um prazo razoável, por um juiz ou tribunal competente, independente e imparcial, estabelecido anteriormente por lei, na apuração de qualquer acusação penal formulada contra ela, ou na determinação de seus direitos e obrigações ou de qualquer outra natureza."
} 
Assim, a indeterminação do aludido conceito ("duração razoável”) se não houver uma integração legislativa ficará "esquecida" dentro da lide.

Sucede que na esfera administrativa tal situação não ocorre, pois mesmo o conceito, como visto, ser indeterminado, a jurisdição é única e não existem todos os recursos colocados à disposição da parte, além do estabelecimento do prazo certo e determinado de 140 (cento e quarenta) dias para a tramitação do processo administrativo disciplinar com a aplicação da penalidade.

Portanto, não existe, em tese, justificativa legal plausível para que a esfera administrativa deixe de cumprir os prazos previamente estabelecidos, como forma de preconizar uma célere e eficiente apuração.

In casu, não é necessária a integração da lei para dar efetividade ao preceito constitucional fundamental da celeridade do processo administrativo disciplinar, visto que os Estatutos dos Funcionários Públicos estabelecem o prazo razoável para a sua tramitação, competindo à Administração Pública o ônus da prova. ${ }^{23}$

Exatamente nesse sentido, extraem-se as seguintes conclusões dos ensinamentos de Irineu Cabral Barreto, membro da Comissão Européia dos Direitos do Homem: "O 'prazo razoável' apresenta-se como uma questão de facto; por isso, o ônus da prova recai sobre o Estado requerido, incumbindo-se, quando o prazo parecer exorbitante, fornecer as explicações sobre os motivos dos atrasos verificados"24 [aspas no original].

Aplica-se a presente lição declinada, pela inversão do ônus da prova no prazo disciplinar, visto que é uma obrigação do Poder Público provar inequivocamente a responsabilidade do servidor público investigado/acusado, através de uma lícita e tempestiva produção de prova. Do contrário aplica-se o princípio in dubio pro reo.

Em decorrência deste novo dispositivo constitucional, o Superior Tribunal de Justiça $\mathrm{a}^{25}$ deferiu habeas corpus impetrado contra a demora no julgamento de revisão criminal que havia ultrapassado o limite razoável a que alude o art. $5^{\circ}$, LXXVIII, CF e ao estabelecido na Convenção Americana dos Direitos Humanos:

\footnotetext{
${ }^{23}$ MATTOS, Mauro Roberto Gomes de. Da presunção de inocência do servidor público no processo disciplinar brasileiro. Revista Ibero-Americana de Direito Público - RIADP, Rio de Janeiro, v. 10, p. 239243, 2. trim.2003.

${ }^{24}$ BARRETO, Irineu Cabral. A Convenção Européia dos Direitos do Homem. Lisboa: Ed. Notícias Aequitas, 1995. p. 100.
} 
Processual Penal. Habeas Corpus. Revisão Criminal. Demora no julgamento. Pendência de distribuição. Limite razoável ultrapassado. Art. 5º, LXXVIII, da CF, e art. $7^{\circ}$, itens 5 e 6, da Convenção Americana de Direitos Humanos. Precedentes do STF E STJ. Constrangimento ilegal caracterizado. Ordem Concedida. Não se admite o decurso de prazo desarrazoadamente longo para o julgamento de qualquer feito judicial, in casu, Revisão Criminal que, até o momento, não foi sequer distribuída. Constituição Federal, art. $5^{\circ}$, inciso LXXVIII, acrescentado pela EC 45/2004: "a todos, no âmbito judicial e administrativo, são assegurados a razoável duração do processo e os meios que garantam a celeridade de sua tramitação". Convenção Americana de Direitos Humanos (Pacto de São José da Costa Rica) - Item 5: "Toda pessoa detida ou retida deve ser conduzida, sem demora, à presença de um juiz ou outra autoridade autorizada pela lei a exercer funções judiciais e tem direito a ser julgada dentro de um prazo razoável ou a ser posta em liberdade, sem prejuízo de que prossiga o processo." Item 6: "Toda pessoa privada da liberdade tem direito a recorrer a um juiz ou tribunal competente, a fim de que este decida, sem demora, sobre a legalidade de sua prisão ou detenção e ordene sua soltura se a prisão ou a detenção forem ilegais." Configura constrangimento ilegal o excesso de prazo injustificado para o julgamento do recurso, sanável via habeas corpus. Ordem concedida. [aspas no original]

Importante este aresto, visto que o Poder Judiciário, mesmo que timidamente, vem demonstrando certa aversão à duração continuada dos processos, que levam a verdadeira indeterminação para sua conclusão.

Na esfera administrativa disciplinar é inconcebível tamanha morosidade, que apenas se justifica por uma ineficiência da Administração Pública, que não consegue solucionar em tempo razoável os processos.

Incumbe à Administração Pública ${ }^{26}$ organizar o seu sistema de apuração disciplinar de modo que a sua jurisdição possa garantir ao investigado o cumprimento do fundamental direito de obter uma decisão definitiva com a duração de tempo razoável, sem ofensa aos princípios do contraditório e da ampla defesa, estabelecidos no art. $5^{\circ}$, LV, da CF.

Compete à Administração Pública, responsável pelo desenvolvimento da apuração administrativa, disciplinar, criar meios e condições que garantam a celeridade do processo. E não é árdua tal tarefa, visto que ela está interligada apenas a força de trabalho e ao aparelhamento

\footnotetext{
25 STJ. HC n 39.427/SP. Relator: Min. Paulo Medina. Órgão julgador: 6a Turma. DJ, p. 571, $1^{\circ}$ ago. 2005.

26 "O comportamento dos órgãos judiciais e administrativos na apreciação do processo, judicial ou administrativo, deve ser analisado de maneira a verificar se o desfecho do processo ocorreu em tempo razoável, nos termos da norma constitucional" (CARVALHO, Fabiano. ECN. 45: reafirmação da garantia da razoável duração do processo. In: WAMBIER, Teresa Arruda Alvim e outros (Coord.). Reforma do Judiciário: primeiras reflexões sobre a Emenda Constitucional n 45/2004. São Paulo: R. dos Tribunais, 2005. p. 210).
} 
da máquina administrativa, que investe, através do pagamento de diárias rendosas aos membros da Comissão Disciplinar, para a plena e eficaz apuração dos fatos investigados.

Em assim sendo, o prazo de duração razoável para a conclusão do processo disciplinar federal é de 60 (sessenta) dias, contados da data de publicação do ato que constituir a Comissão, podendo ser prorrogado por igual período (art. 152, da Lei $\mathrm{n}^{\circ} 8.112 / 90$ ).

Na prática, este prazo é totalmente desconsiderado pelas Comissões Disciplinares, como deixamos averbado em outra oportunidade: ${ }^{27}$ "O que era para ser célere, pelo princípio da oficialidade, com o término dos trabalhos em até 60 (sessenta) dias, quase sempre é prorrogado por período superior ao previsto, ficando indefinida a conclusão."

Possuindo no total 120 (cento e vinte) dias para a conclusão do processo administrativo disciplinar, a Comissão Disciplinar deve remeter o feito para a Autoridade julgadora, que possui 20 (vinte) dias, contados do recebimento do mesmo, para proferir a sua decisão. Portanto, o prazo de duração razoável estabelecido pelo legislador é de 140 (cento e quarenta) dias, contados a partir da instauração do processo administrativo disciplinar, com a nomeação dos membros que irão compor a Comissão processante.

Excedido este prazo, sem justo motivo, haverá um ato inconstitucional praticado pelo Poder Público, visto que o disposto no art. $5^{\circ}$, LXXVIII, da CF é uníssono em determinar que a duração do processo administrativo seja em prazo razoável.

Sobre o excesso de prazo, o professor Hélio Tornaghi já manifestava o seu inconformismo com a indefinição da conclusão de um processo: "Ainda que haja motivo justo, o excesso de prazo não é indefinido."

Dessa forma, deve a Administração Pública cumprir o que vem estabelecido no art. $5^{\circ}$, LXXVIII, da CF, concluindo e julgando os seus processos disciplinares em até 140 (cento e quarenta) dias, contados da instauração dos mesmos, sob pena de ferir um direito fundamental do servidor público acusado a ser investigado em um prazo de duração razoável, previsto na Lei infraconstitucional.

\footnotetext{
${ }^{27}$ MATTOS, Mauro Roberto Gomes de. Lei no 8.112/90 Interpretada e Comentada: Regime Jurídico Único dos Servidores Públicos da União. 3. ed., revista, ampliada e atualizada. Rio de Janeiro: América Jurídica, 2005. p. 918.
}

A \& C R. de Dir. Administrativo e Constitucional, Belo Horizonte, ano 7, n. 28, p. 129-149, abr./jun. 2007 


\section{Afastamento das funções judicantes do magistrado em razão de processo disciplinar não pode exceder 120 dias}

Como já dito alhures, a LOMAN não estabelece prazos processuais para os processos disciplinares contra Magistrados, cabendo, desta forma, ao Regimento Interno do Conselho Nacional de Justiça (CNJ), dispor sobre a matéria, em seu artigo 83, onde determina aplicar, no que não for incompatível, a Lei $\mathrm{n}^{\circ} 8.112 / 90$ e a Lei $\mathrm{n}^{\circ} 9.784 / 99$, verbis:

Art. 83 - O processo disciplinar instaurado contra magistrado obedecerá ao procedimento da Lei Orgânica da Magistratura, inclusive no que concerne à aplicação pelo Conselho das penas disciplinares, aplicando-se no que não for incompatível, a Lei $n^{\circ} 8.112 / 90$ e a Lei no 9.784/99.

Destarte, ao recomendar a aplicação aos Magistrados do prazo de afastamento preventivo estipulado pela Lei $\mathrm{n}^{\circ}$ 8.112/90 aos servidores públicos federais, não poderá, em hipótese alguma, o juiz/acusado ficar afastado de suas funções por mais de 120 dias.

Isto porque o artigo 147, da Lei $n^{\circ} 8.112 / 90$, determina expressamente que, como medida cautelar, a fim de que o servidor não venha a influir na apuração do Processo Administrativo Disciplinar, poderá o acusado ser afastado do exercício de seu cargo pelo prazo de até 60 (sessenta) dias, prorrogáveis por igual período (parágrafo único do art. 147, verbis):

Art. 147 - Como medida cautelar e a fim de que o servidor não venha a influir na apuração da irregularidade, a autoridade instauradora do processo disciplinar poderá determinar o seu afastamento do exercício do cargo, pelo prazo de até 60 (sessenta) dias, sem prejuízo da remuneração.

Parágrafo Único - O afastamento poderá ser prorrogado por igual prazo, findo o qual cessarão os seus efeitos, ainda que não concluído o processo.

Dessa forma, o afastamento preventivo que excede 120 (cento e vinte) dias (prazo estabelecido pelo art. 147, da Lei $\mathrm{n}^{\circ}$ 8.112/90) é ilegal, como decidido por este CNJ nos precedentes PCA n ${ }^{\text {os }} 122$ e 214.

Isto porque o afastamento liminar é estabelecido para evitar que o agente público cause prejuízo na instrução do processo disciplinar, como diz textualmente o caput do art. 147, da Lei $\mathrm{n}^{\circ}$ 8.112/90, utilizado subsidiariamente ao processo disciplinar do Magistrado por imposição regimental do CNJ: "A fim de que o servidor não venha a influir na apuração de irregularidade."

Desta forma, pelo princípio da moralidade, norma assente no caput

A \& C R. de Dir. Administrativo e Constitucional, Belo Horizonte, ano 7, n. 28, p. 129-149, abr./jun. 2007 
do art. 37, da CF, é exigido da Administração Pública uma submissão ao interesse público, afastando o agente público/magistrado que realmente atrapalhe ou influencie a instrução processual, e mantendo em suas funções aqueles que não causam transtornos ou prejudiquem a investigação.

Neste sentido, defendemos ${ }^{28}$ em outra oportunidade, o afastamento do servidor público investigado disciplinarmente pelo prazo de até 120 dias: "O afastamento do servidor público por mais de 120 dias torna-se ilegal e dá azo ao pedido de suspensão dessa penalidade, tendo em vista que este é o limite temporal aceitável pelo legislador."

E os Tribunais Superiores, seguindo rigorosa sintonia com a orientação do CNJ (PCA n ${ }^{\text {os }} 122$ e 214), também declaram expressamente a ilegalidade na extrapolação do prazo de afastamento cautelar do servidor público investigado disciplinarmente: "Administrativo. Processo Administrativo Disciplinar. Afastamento Preventivo (art. 147 da Lei no 8.112/90 ). Ilegalidade na extrapolação do prazo. O prazo de sessenta dias, prorrogável por igual período, previsto no art. 147 da Lei n ${ }^{\circ} 8.112 / 90$, não pode ser extrapolado, sob pena de tornar-se abusivo o afastamento, passando a constituir ilegalidade corrigível por via mandado de segurança."29 "Administrativo. Mandado de Segurança. Professor da Universidade de Brasília. Afastamento Preventivo. Lei no 8.112/90, art. 147. Medida Cautelar. Prazo de 60 (sessenta) dias prorrogável por igual período. Excesso de Prazo. Ilegalidade. Desvio de Finalidade. 1. Como medida cautelar e a fim de que o servidor não venha a influir na apuração da irregularidade, a autoridade instauradora do processo disciplinar poderá determinar o seu afastamento do exercício do cargo, pelo prazo de até 60 (sessenta) dias, prorrogável por igual período, sem prejuízo da remuneração (art. 147 e seu parágrafo único da Lei $\left.\mathrm{n}^{\circ} 8.112 / 90\right)$. 2. Constitui ofensa a direito líquido e certo do impetrante, bem como, ilegalidade e desvio de poder, a manutenção do afastamento do servidor do exercício de seu cargo posteriormente ao esgotamento do prazo legal da medida cautelar e sem que haja sido concluído o processo disciplinar. 3. Sentença monocrática determinando o retorno do impetrante às suas atividades na Administração confirmada. 4. Remessa oficial a que se nega provimento." 30

\footnotetext{
${ }^{28}$ MATTOS, Mauro Roberto Gomes de. Lei no 8.112/90 interpretada e comentada - regime jurídico único dos servidores públicos da União. 3. ed. Rio de Janeiro: América Jurídica, 2006. p. 882.

${ }^{29}$ BRASIL. Tribunal Regional Federal (4. Região). REO n 95.04.534317/PR. Órgão julgador: 4a Turma. Relator: Des. Fed. Luiz Carlos de Castro Lugon. DJ, p. 651, 19 maio 1999.
} 
Ora, o prejuízo do afastamento do Magistrado, por mais de 120 dias é de toda a coletividade, visto que ele recebe os seus vencimentos sem se encontrar no exercício de suas funções judicantes, apesar de haver déficit de juízes em quase todas as comarcas, em face do grande acúmulo de ações.

Assim sendo, tal afastamento compromete o princípio da legalidade e da moralidade, pois não se admite o excesso de prazo já declinado (120 dias) de inatividade do juiz acusado disciplinarmente.

Como dito pelo ilustre Conselheiro do CNJ, Joaquim Falcão: "Um Judiciário mais poderoso exige um Judiciário mais ágil, ético e transparente. São, pois, faces da mesma moeda: a consolidação institucional da democracia brasileira. Há algumas décadas, a sociedade centrou esta busca da eficiência, da moralidade e da transparência na criação de um órgão nacional capaz de atingir estes objetivos, exercendo um controle que se mostrava dia após dia mais e mais necessário. Todos se lembram do controle externo da magistratura. Foram escritas e debatidas dezenas de projetos e anteprojetos que nunca lograram êxito. Mas teve destino distinto e bem-sucedido a Emenda Constitucional 45/04, resultado de uma aliança pouco comum na história legislativa brasileira, um verdadeiro pacto entre os três poderes da República."

A seguir o ilustre Conselheiro do CNJ Joaquim Falcão, ${ }^{31}$ com acerto, define bem o tema sub oculis da seguinte forma: "Nesse passo, vale a pena chamar a atenção para o fato de que a própria Emenda Constitucional $\mathrm{n}^{\mathrm{o}} 45 / 2004$ contém provisões adequadas a garantir que o exercício do poder disciplinar se paute por critérios de rigorosa legalidade."

O não menos ilustre Conselheiro e eminente constitucionalista, Alexandre de Moraes, ${ }^{32}$ a respeito da desburocratização/celeridade dos processos administrativos e judiciais, destaca: "Em relação a maior celeridade processual, a EC $\mathrm{n}^{\mathrm{o}} 45 / 04$ (reforma do Judiciário) assegurou a todos, no âmbito judicial e administrativo, a razoável duração do processo e os meios que garantam a celeridade de sua tramitação (...) Os processos administrativos e judiciais devem garantir todos os direitos às partes, sem, contudo, esquecer a necessidade de desburocratização de seus procedimentos e a busca de qualidade e máxima eficácia de suas decisões (...) O

\footnotetext{
${ }^{30}$ BRASIL. Tribunal Regional Federal (1. Região). REO n 01337006/DF. Órgão julgador: $1^{\text {a }}$ Turma. Relator: Des. Fed. Amilcar Machado. DJ, p. 2495, nov. 2001.

${ }^{31}$ FALCÃO, Joaquim. Separação de poderes e a independência do Poder Judiciário. RDA, São Paulo, n. 243, p. 236, set./dez. 2006.
} 
Conselho Nacional de Justiça, visando dar plena efetividade ao princípio da celeridade processual e razoável duração do processo, bem como atacar a morosidade na tramitação e julgamento dos processos, nos termos do art. 80, de seu Regimento Interno, instituiu a representação por excesso injustificado de prazo contra o Magistrado, que poderá ser formulada por qualquer interessado, pelo Ministério Público, pelos Presidentes de Tribunais ou, de ofício, pelos Conselheiros..."

Desta forma, após 120 dias de afastamento de suas funções, o Magistrado investigado poderá ingressar com Procedimento de Controle Administrativo (PCA), perante o Conselho Nacional de Justiça, solicitando o deferimento de medida liminar, em igualdade de condições com os PCAs n ${ }^{\text {os }} 122$ e 214 do CNJ, para que ele seja reconduzido às suas funções judicantes.

Não há justificativa legal para o excesso do prazo da apuração disciplinar, bem como a manutenção do afastamento do agente público investigado por mais de 120 dias. Haverá abuso de poder do órgão apurador, com violação explícita dos direitos e das garantias fundamentais do Magistrado.

\section{Conclusão}

O Conselho Nacional de Justiça (CNJ), ao determinar, no artigo 83 de seu Regimento Interno, a aplicação da Lei $\mathrm{n}^{\circ} 8.112 / 60$ e da Lei $\mathrm{n}^{\mathrm{o}} 9.784 / 99$, no que não for incompatível com a LOMAN, ao processo disciplinar instaurado contra Magistrado, deu um importante passo para a moralização e para a celeridade dos feitos administrativos, visto que existem regras objetivas que deverão ser seguidas, excetuando-se a indesejada e indiscriminada discricionariedade da Comissão Disciplinar, que eternizava a respectiva apuração, até o seu desfecho final.

Este grande avanço resgata a credibilidade das apurações disciplinares dos Magistrados, que, antes do resultado final do julgamento, condenava o investigado a um afastamento de suas funções ad eternum, em uma lenta apuração.

Agora não é mais permitido o excesso de morosidade nas investi-

\footnotetext{
32 MORAES, Alexandre de. Conselho Nacional de Justiça e Efetivação da Celeridade Processual - Procedimento por excesso de prazo. RDA, São Paulo, n. 243, p. 278-280, set./dez. 2006.
}

A \& C R. de Dir. Administrativo e Constitucional, Belo Horizonte, ano 7, n. 28, p. 129-149, abr./jun. 2007 
gações, devendo o procedimento ser concluído em até 140 dias e o Magistrado acusado/investigado ficar ausente de suas funções por mais de 120 dias.

Excedido os aludidos prazos, cabe ao interessado se socorrer do CNJ, para que este Col. Conselho resgate a dignidade do Magistrado e determine a sua imediata reintegração às suas funções, bem como estabeleça prazo para o término do processo administrativo disciplinar contra o Juiz.

Informação bibliográfica deste texto, conforme a NBR 6023:2002 da Associação Brasileira de Normas Técnicas (ABNT):

MATTOS, Mauro Roberto Gomes de. Afastamento da função jurisdicional de magistrado, em virtude de processo administrativo disciplinar, não poderá exceder 120 dias - Inteligência do art. 147, da Lei n 8.112/90. A\&C Revista de Direito Administrativo e Constitucional, Belo Horizonte, ano 7, n. 28, p. 129-149, abr./jun. 2007. 